\title{
Aktivitas Penangkapan Radikal Bebas DPPH dan Daya Reduksi Ekstrak Gracilaria verrucosa
}

\author{
DPPH Free Radical Catching Activities and Reduction Power of Graciliaria \\ verrucosa Extract
}

\author{
Anggi Setiabudi ${ }^{1}$, Delianis Pringgenies ${ }^{2 *}$, Ali Ridlo ${ }^{3}$ \\ Departemen Ilmu kelautan, Fakultas Perikanan dan Ilmu Kelautan, Universitas Diponegoro \\ Jl. Prof. Soedarto, SH. Kampus UNDIP Tembalang, Semarang 50275 \\ *email:delianispringgenies@lecturer.undip.ac.id
}

DOI;
10.30595/jrst.v4i2.5761

Histori Artikel:

Diajukan:

$24 / 10 / 2019$

Direvisi:

$01 / 16 / 2020$

Diterima:

07/09/2020

\section{ABSTRAK}

Gracilaria verrucosa adalah salah satu jenis rumput laut merah yang memiliki kandungan bioaktif untuk antioksidan alami. Penelitian ini bertujuan untuk mengetahui aktivitas antioksidan yang terkandung di dalam Gracilaria verrucosa dengan menggunakan dua metode berbeda, yaitu penangkapan radikal bebas DPPH dan daya reduksi dengan menggunakan tiga pelarut berbeda ( $\mathrm{n}$ - heksan, etil asetat dan metanol), mengetahui nilai total fenolat dan pigmen (klorofil a, klorofil $\mathrm{b}$ dan karotenoid). Penentuan total fenolat menggunakan asam galat sebagai standar dengan Folin - Ciocalteu sebagai pelarutnya. Penentuan pigmen klorofil a, klorofil b dan karotenoid dilakukan dengan spektrofotometri UV - VIS dengan Panjang gelombang $646 \mathrm{~nm}$, $663 \mathrm{~nm}$ dan $470 \mathrm{~nm}$. Hasil penelitian menunjukkan bahwa ekstrak Gracilaria verrucosa memiliki aktivitas antioksidan sangat lemah dengan nilai IC50 ekstrak etil asetat 1.274 ppm, ekstrak n - heksan 1.304 ppm dan ekstrak metanol 1.381 ppm sedangkan aktivitas antioksidan dengan daya reduksi menunjukkan nilai antioksidan ekstrak etil asetat 15,13 mgAAE/gr sampel; ekstrak n - heksan 8,50 mgAAE/gr sampel dan ekstrak metanol 5,85 mgAAE/gr sampel.

Kata Kunci: Gracilaria verrucosa, antioksidan, DPPH, Daya reduksi

\begin{abstract}
Gracilaria verrucosa is one of the red seaweed that is potentially used as a natural antioxidant. This study aims to determine the antioxidant activity contained in Gracilaria verrucosa used two different methods, are DPPH free radical scavenging and reduction power with three different solvents based on polarity ( $\mathrm{n}$ - hexane, aetyl acetat and methanol), to determine total phenolic and pigments (chlorophyll a, chlorophyll b and carotenoid). Determination of total phenolics used gallic acid as a standard with Folin - Ciocalteu as solvent. Determination pigment of chlorophyll a, chlorophyll b and carotenoid did with spektrofotometri UV - VIS with wavelength $646 \mathrm{~nm}, 663 \mathrm{~nm}$ and $470 \mathrm{~nm}$. The result showed that antioxidant activity of Gracilaria verrucosa aetyl acetat extract have very weak with IC50 1,274 ppm, $\mathrm{n}$ - hexane extract 1,304 ppm and methanol extract 1,381 ppm while antioxidant activity with reduction power showed antioxidant value of aetyl acetat extract 15,13 mgAAE/gr sample, $\mathrm{n}$ - hexane extract $8.50 \mathrm{mgAAE} / \mathrm{gr}$ sample and methanol extract $5.85 \mathrm{mgAAE} / \mathrm{gr}$ sample.
\end{abstract}

Keywords: Gracilaria verrucosa, antioxidant, DPPH, Reduction power 


\section{PENDAHULUAN}

Penyakit degeneratif merupakan penyakit berbahaya yang diakibatkan karena adanya kerusakan sel akibat adanya reaktivitas dari senyawa radikal bebas, penyakit ini tidak langsung muncul akan tetapi melalui proses bertahun - tahun, penyakit ini menjadi kematian terbesar di Indonesia, contoh dari penyakit degeneratif yaitu kanker, stroke, diabetes melitus dan penuaan dini (Indrawati et al., 2009; Meydani, 2000; Wijaya, 1996). Radikal bebas adalah reaksi kimia yang tidak memiliki elektron berpasangan pada bagian terluarnya, karena tidak memiliki elektron yang berpasangan radikal bebas ini bersifat sangat reaktif dan mencari pasangan elektron dari senyawa lain, akibatnya akan terbentuk rantai radikal baru yang terus memanjang dan merusak struktur senyawa tertentu, radikal hidroksil, radikal peroksil dan anion superoksida merupakan contoh dari senyawa radikal bebas (Gordon MH et al., 2001). Antioksidan adalah senyawa kimia yang dapat memutus reaksi rantai radikal bebas, yang kemudian dapat mencegah terjadinya proses biologis dalam tubuh yang dapat membahayakan dan merugikan. Senyawa antioksidan memiliki peran yang penting sebagai faktor pelindung, karena senyawa tersebut dapat menunda atau menghalangi oksidasi lipid dengan cara menghambat terjadinya reaksi berantai oksidasi (Picolella et al., 2008).

Berdasarkan sumbernya antioksidan terbagi menjadi antioksidan endogen dan antioksidan eksogen. Antioksidan endogen adalah antioksidan yang diproduksi secara alami dalam tubuh seperti Superoksida Dismutase (SOD), Katalase (CAT) dan Glutasion Peroksidase (GPx) (Agregan et al., 2017; McCord dan Fridovitch, 1969). Antioksidan eksogen terbagi lagi menjadi dua bagian yaitu antioksidan alami dan antioksidan buatan, antioksidan alami didapat dari tumbuh - tumbuhan dan sayuran seperti karotenoid, vitamin $A$, vitamin $C$ dan $\beta$ karoten, sedangkan antioksidan sintetik atau buatan yaitu antioksidan yang diperjualbelikan secara luas dan biasanya menjadi campuran pada makanan dan minyak, contohnya yaitu Butil Hidroksil Toluen (BHT), Butil Hidroksil Anisol (BHA) dan Tert - Butil Hidroksil Quinon (TBHQ), antioksidan sintetik memiliki sifat karsinogenik (dapat menyebabkan kanker) jika digunakan melebihi batas aman penggunaan yaitu $0,02 \%$ dari kandungan lemak atau minyak), oleh karena itu penggunaan antioksidan alami sangat diperlukan (Atta et al., 2017). Salah satu organisme laut yang dapat digunakan sebagai antioksidan alami yaitu Gracilaria verrucosa.

Gracilaria verrucosa merupakan salah satu rumput laut merah (Rhodophyta) yang dapat dimanfaatkan sebagai antioksidan dan antiinflamasi (Widowati et al., 2014; Almeida et al., 2011). Gracilaria verrucosa memiliki kandungan seperti pikoloid, agar, karagenan, klorofil, fikobilin yang terdiri dari fikosianin dan fikoeritrin, protein, lemak, kalium, besi, iodium, belerang, fosfor, kalsium dan brom (Fleurence and Ira, 2016). Penelitian ini bertujuan untuk mencari tahu nilai aktivitas antioksidan ekstrak Gracilaria verrucosa, dengan menggunakan dua metode yang berbeda yaitu metode penangkapan radikal bebas DPPH dan metode daya reduksi dan mencari nilai total fenolat serta pigmen dari eksrak G. verrucosa.

\section{MATERI DAN METODE}

Materi dalam penelitian ini yaitu rumput laut Gracilaria verrucosa yang didapatkan dari tambak Balai Besar Perikanan dan Budidaya Air Payau (BBPBAP) Jepara, Jawa Tengah. Alat yang digunakan adalah rotary evaporator untuk mendapatkan hasil ekstraksi dan Spektrofotometri UV - VIS- Shimadzu untuk mendapatkan data penangkapan radikal bebas DPPH. Metode deskriptif eksploratif digunakan dalam penelitian ini, beberapa tahapan metode dalam penelitian ini yaitu.

\subsection{Ekstraksi sampel}

Preparasi sampel; ekstraksi; uji penangkapan radikal bebas DPPH; Uji kandungan total fenolat; uji kandungan pigmen klorofil a, klorofil b dan karotenoid dan uji daya reduksi. Gracilaria verrucosa diambil dari tambak BBPBAP, lalu dicuci dan dikeringkan pada suhu ruang $\left(27^{\circ} \mathrm{C}\right)$, selanjutnya dipotong kecil kecil dan dimasukkan ke dalam toples kaca untuk dimaserasi.

Sampel rumput laut $G$. verrucosa dimaserasi dengan tiga pelarut berbeda, yaitu: pelarut $\mathrm{n}$ - heksan, etil asetat dan metanol. Sampel G. verrucosa kering dalam toples kaca direndam dengan satu liter pelarut $\mathrm{n}$ - heksan, kemudian residu direndam dengan etil asetat dan metanol, masing - masing perendaman dilakukan selama 1 x 24 jam. Maserat lalu diuapkan dengan rotary evaporator dan dipekatkan dengan gas nitrogen. Nilai rendemen dihitung dengan rumus sebagai berikut (Mulangsri et al., 2017): 
Rendemen $=($ Berat ekstrak $) /($ Berat sampel $) \mathrm{x}$ $100 \%$

2.2 Uji Penangkapan Radikal Bebas DPPH (1,1 - dyphenil - 2 - picrylhydrazyl).

Pengujian penangkapan radikal bebas DPPH dilakukan dengan mengacu kepada Amri (2018); Miliauskas et al., (2004); Leong dan Shui (2002). Ekstrak Gracilaria verrucosa dibuat dengan konsentrasi $62,5 \mathrm{ppm}, 125 \mathrm{ppm}, 250 \mathrm{ppm}$ dan 500 ppm. Masing - masing diambil $1 \mathrm{ml}$, dan ditambahkan dengn $3 \mathrm{ml} \mathrm{0,1} \mathrm{mM}$ larutan DPPH. Campuran diinkubasi selama 30 menit pada kondisi gelap dan absorbansi diukur dengan spektrofotometri UV - VIS Panjang gelombang $517 \mathrm{~nm}$. Persentase penangkapan radikal bebas DPPH dihitung dengan rumus berikut (Bajpai et al., 2017; Gouda et al., 2013):

Inhibisi $(\%)=((A-B)) / A \times 100$

Keterangan :

$\mathrm{A}=$ Absorbansi larutan DPPH

B =Absorbansi larutan DPPH ditambah ekstrak

\subsection{Uji Kandungan Total Fenolat}

Dilakukan dengan menimbang $5 \mathrm{mg}$ ekstrak yang dilarutkan dalam $2 \mathrm{ml}$ etanol p.a lalu ditambahkan $5 \mathrm{ml}$ akuades dan 0,5 ml reagen Folin - Ciocalteu 50\%. Campuran diinkubasi selama 5 menit dan ditambahkan $\mathrm{Na}_{2} \mathrm{CO}_{3} 5 \%$ sebanyak $1 \mathrm{ml}$, absorbansi diukur pada Panjang gelombang $725 \mathrm{~nm}$ dan asam galat dibuat dengan seri konsentrasi 5, 10, 15, 20 dan $25 \mathrm{mg} / \mathrm{l}$, kurva sama galat dibuat untuk mengetahui nilai senyawa fenolat dangan persamaan regresi. Total fenolat dihitung dengan rumus berikut :

Total Fenolat $=((\mathrm{a} \times \mathrm{V}) / 1000) / \mathrm{G}$

Keterangan :

a = Konsentrasi asam galat dalam sampel uji (mg/l)

$\mathrm{V}=$ volume total larutan uji (mL)

$\mathrm{G}=$ Berat ekstrak yang digunakan (gr)

1000 = faktor konversi terhadap volume total larutan $(\mathrm{mL})$

\subsection{Uji Pigmen}

Uji pigmen seperti klorofil a, klorofil b dan karotenoid dilakukan dengan menggunakan metode yang mengacu kepada Lichtenthaler (1987), ekstrak ditimbang 5 mg dan ditambahkan
$5 \mathrm{ml}$ aseton p.a. absorbansi dihitung dengan rumus berikut :

$$
\begin{array}{ll}
\text { Klorofil a } & =12,21 \times \mathrm{A} 663-2,81 \times \mathrm{A} 646 \\
\text { Klorofil b } & =20,13 \times \mathrm{A} 663-5,03 \times \mathrm{A} 663 \\
\text { Karotenoid } & =((\mathrm{A} 470+0,114 \times \mathrm{A} 663-0,638 \times \\
\text { A646) } \times \mathrm{V} \times 1000)) /(112,5 \times 0,1 \times 10)
\end{array}
$$

\subsection{Uji Daya Reduksi}

Pengujian daya reduksi dilakukan dengan pembuatan larutan buffer fosfat, yang dibuat dengan cara menimbang 2 gr $\mathrm{NaOH}$ dilarutkan dalam akuades bebas CO2 hingga $250 \mathrm{ml}$. KH2PO4 ditimbang sebanyak 6,8 gr dilarutkan dalam akuades bebas $\mathrm{CO} 2$ hingga $250 \mathrm{ml}$. NaOH sebanyak 16,4 ml dicampurkan dengan $50 \mathrm{ml}$ KH2PO4 dan diukur hingga $\mathrm{pH}$ menunjukkan nilai 6,6 dan dicukupkan dengan akuades bebas CO2 sampai $200 \mathrm{ml}$ (Maryam et al., 2016). Larutan blanko daya reduksi dibuat dengan cara $1 \mathrm{ml}$ asam oksalat $1 \%$ ditambahkan dengan $1 \mathrm{ml}$ larutan buffer fosfat $(0,2 \mathrm{M} \mathrm{pH} \quad 6,6)$ dan ditambahkan $1 \mathrm{ml}$ K3Fe(CN)6 1\%. Campuran diinkubasi selama 20 menit pada suhu 500C, ditambah TCA $10 \%$ sebanyak $1 \mathrm{ml}$, disentrifuge pada 3.000 rpm selama 10 menit. Larutan diambil $1 \mathrm{ml}$ dan ditambah dengan $1 \mathrm{ml}$ akuades dan 0,5 $\mathrm{ml} \mathrm{FeCl3} \mathrm{1 \% .} \mathrm{Absorbansi} \mathrm{diukur} \mathrm{pada} \mathrm{Panjang}$ gelombang $692 \mathrm{~nm}$ (Tahir et al., 2016).

Larutan standar dibuat dengan melarutkan $1 \%$ asam oksalat dengan $25 \mathrm{mg}$ asam askorbat diencerkan hingga $25 \mathrm{ml}$, masing - masing diambil 0,$4 ; 0,5 ; 0,6 ; 0,7$ dan $0,8 \mathrm{ml}$ dan diencerkan dengan asam oksalat $1 \%$ hingga 10 ml. diambil larutan tersebut $1 \mathrm{ml}$ dan dicampur dengan $1 \mathrm{ml}$ larutan buffer fosfat $(0,2 \mathrm{M} \mathrm{pH} \mathrm{6,6)}$ dan $1 \mathrm{ml} \mathrm{K} 3 \mathrm{Fe}(\mathrm{CN}) 6$ 1\% campuran diinkubasi selama 20 menit suhu 500C. campuran ditambah $1 \mathrm{ml}$ TCA diaduk selama 10 menit dan disentrifuge selama 10 menit kecepatan 3.000 rpm. Diambil $1 \mathrm{ml}$ dan ditambahkan 0,5 ml FeCl3 0,1\% dan $1 \mathrm{ml}$ akuades, absorbansi diukur pada Panjang gelombang $692 \mathrm{~nm}$ (Tahir et al., 2016; Oyaizu, 1986).

Pengenceran ekstrak dilakukan dengan mengambil $5 \mathrm{mg}$ masing - masing ekstrak dilarutkan dengan $5 \mathrm{ml}$ etanol p.a, diambil $1 \mathrm{ml}$ dan ditambahkan larutan buffer fosfat $(0,2 \mathrm{M} \mathrm{pH}$

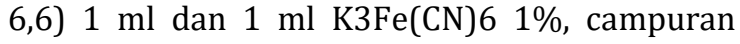
diinkubasi selama 20 menit suhu 500C. ditambah $1 \mathrm{ml}$ TCA dan disentrifuge kecepatan $3.000 \mathrm{rpm}$ selama 10 menit, lapisan atas diambil $1 \mathrm{ml}$ dan ditambahkan dengan $1 \mathrm{ml}$ akuades dan $0,5 \mathrm{ml}$ 
FeCl3 0,1\%, campuran diukur absorbansinya pada $692 \mathrm{~nm}$ (Tahir et al., 2016).

\section{HASIL DAN PEMBAHASAN}

\subsection{Rendaman hasil ekstraksi}

Ekstraksi dilakukan menggunakan tiga pelarut yang berbeda berdasarkan polaritasnya. Ekstraksi dengan metanol menghasilkan rendemen tertinggi yaitu $1,90 \%$ lalu etil asetat $0,17 \%$ dan $\mathrm{n}$ - heksan $0,08 \%$. Tujuan dari ekstraksi untuk memperoleh senyawa bioaktif dalam sampel (Harborne, 1987). Nilai metanol yang tinggi menunjukkan bahwa ekstrak G. verrucosa memiliki senyawa polar lebih banyak dibandingkan dengan senyawa non - polar (Gritter et al., 1991).

\subsection{Kandungan fenolat}

Kandungan total fenolat tertinggi ada pada ekstrak etil asetat dengan 52,105 mgGAE/gr sampel, kemudian ekstrak n - heksan 43,265 mgGAE/gr sampel dan ekstrak metanol 20,130 mgGAE/gr sampel.

\subsection{Kandungan Pigmen}

Kandungan klorofil a tertinggi ada pada ekstrak etil asetat dengan $3,577 \mathrm{mg} / \mathrm{gr}$ sampel, ekstrak metanol 0,536 mg/gr sampel dan $\mathrm{n}$ heksan $0,521 \mathrm{mg} / \mathrm{gr}$ sampel. Etil asetat memiliki nilai tertinggi pada pengujian klorofil dengan 4,681 mg/gr sampel, lalu ekstrak metanol 0,739 mg/gr sampel dan ekstrak n - heksan 0,679 $\mathrm{mg} /$ gr sampel. Karotenoid tertinggi pada ekstrak $\mathrm{n}$ - heksan 15,897 mg/gr sampel, etil asetat $11,688 \mathrm{mg} / \mathrm{gr}$ ssampel dan metanol 1,244 mg/gr sampel.

Hasil total fenolat menunjukkan bahwa etil asetat memiliki kandungan total fenolat, klorofil a dan klorofil $b$ tertinggi dibandingkan dengan pelarut lainnya, yaitu total fenolat 52,105 mgGAE/gr sampel, klorofil a 3,577 mg/gr sampel dan klorofil b 4,681 mg/gr sampel. Klorofil a memiliki sifat kurang polar (Mlodzinska, 2009). Karotenoid tertinggi ada pada ekstrak $\mathrm{n}$ - heksan yaitu $15,897 \mathrm{mg} / \mathrm{gr}$ sampel, dimana hal ini diduga kandungan karotenoid dalam sampel termasuk golongan yang non - polar seperti $\alpha$ karoten dan $\beta$ karoten. Senyawa karoten memiliki kandungan hidrokarbon tak jenuh, yang mengakibatkan dapat melarutkan senyawa karoten yang polar (Pramesti et al., 2017). Kondisi lingkungan, jenis spesies, lokasi tumbuh, umur, musim dan kondisi geografis adalah hal - hal yang dapat mempengaruhi variasi kandungan pigmen yang terkandung dalam suatu sampel (Fleurence and Ira, 2016).

Tingginya nilai total fenolat dalam pelarut etil asetat menunjukkan bahwa senyawa fenolat yang terkandung didalam $\mathrm{G}$. verrucosa bersifat semipolar. Senyawa fenolat terbanyak tidak sepenuhnya berada dalam ekstrak poar (Harborne, 1987) akan tetapi tergantung pada senyawa fenolat yang terkandung dalam sampel (Sheikh et al., 2009).

Ekstrak etil asetat dapat menghasilkan kandungan fenolat paling tinggi, dimana etil asetat lebih efektif melarutkan senyawa fenolat daripada senyawa metanol dan $\mathrm{n}$ - heksan, etill asetat merupakan salah satu pelarut yang sering digunakan untuk mengekstrak senyawa fenolat (Adawiyah et al., 2001). Senyawa fenolat yang terkandung dalam algae dapat menangkap senyawa oksigen reaktif (ROS), menetralkan radikal bebas dan modulator enzim untuk mencegah terjadinya oksidasi lemak, akibatnya senyawa fenolat memiliki pengaruh terhadap aktivitas antioksidan (Pise et al., 2010). Senyawa fenolat juga dapat meredam proses radikal bebas dengan cara mentransfer atom hidrogen radikal peroksil lemak (Heo et al., 2006).

\subsection{Uji antioksidan dengan DPPH}

Pengujian antioksidan dengan penangkapan radikal bebas DPPH dilakukkan dengan cara menghitung nilai absorbansi DPPH yang dikurangi dengan nilai absorbansi DPPH ditambah ekstrak. Parameter untuk mengetahui nilai antioksidan adalah $\mathrm{IC}_{50}$. Semakin tinggi nilai IC50 artinya kekuatan antioksidan yang dimilikiny semakin lemah dan sebaliknya (Raudonis et al., 2012). Nilai IC50 yang didapatkan dalam pengujian ekstrak $\mathrm{n}$ - heksan adalah $1.304 \mathrm{ppm}$, ekstrak etil asetat $1.274 \mathrm{ppm}$ dan ekstrak metanol $1.381 \mathrm{ppm}$. Kontrol positif yang digunakan adalah asam askorbat dengan nilai 59,235 ppm. Asam askorbat digunakan sebagai perbandingan nilai kekuatan antioksidan. 
Tabel 1. Hasil Ekstrak Gracilaria verrucosa

\begin{tabular}{ccccc}
\hline Pelarut & Bentuk & Warna & Berat Ekstrak (gr) & Rendemen Esktrak (\%) \\
\hline n - Heksan & Cair & Merah Kekuningan & 0,19 & 0,08 \\
Etil Asetat & Pasta & Hijau kehitaman & 0,35 & 0,17 \\
Metanol & Padat & Hijau & 3,8 & 1,90 \\
\hline
\end{tabular}

Tabel 2. Nilai Total Fenolat dan Pigmen Gracilaria verrucosa

\begin{tabular}{ccccc}
\hline Pelarut & $\begin{array}{c}\text { Total Fenolat (mg } \\
\text { GAE/gr) }\end{array}$ & $\begin{array}{c}\text { Klorofil a (mg/g } \\
\text { sampel) }\end{array}$ & $\begin{array}{c}\text { Klorofil b } \\
\text { (mg/gr } \\
\text { sampel) }\end{array}$ & $\begin{array}{c}\text { Karotenoid (mg/gr } \\
\text { sampel) }\end{array}$ \\
\hline n- heksan & 43,265 & 0,521 & 0,679 & 15,897 \\
Etil asetat & 52,105 & 3,577 & 4,681 & 11,688 \\
Metanol & 20,213 & 0,536 & 0,739 & 1,244 \\
\hline
\end{tabular}

Tabel 3. Nilai penangkapan radikal bebas DPPH

\begin{tabular}{cccccc}
\hline Ekstrak & Konsentrasi & $\begin{array}{c}\text { Abs. } \\
\text { DPPH }\end{array}$ & $\begin{array}{c}\text { Abs DPPH } \\
\text { + Ekstrak }\end{array}$ & \% Inhibisi & IC 50 \\
\hline n - heksan & 62,5 & & 0,6795 & 31,78 & \\
& 125 & & 0,6535 & 34,39 & 1.304 \\
& 250 & 0,996 & 0,6343 & 36,32 & \\
Etil asetat & 500 & & 0,6134 & 38.41 & \\
& 62,5 & & & & \\
& 125 & & 0,6769 & 32,04 & \\
& 250 & 0,996 & 0,6622 & 33,51 & \\
Metanol & 500 & & 0,6421 & 35,53 & \\
& 62,5 & & & 38,56 & \\
& 125 & & 0,7049 & 29,23 & \\
& 250 & 0,996 & 0,6886 & 30,86 & \\
& 500 & & 0,6558 & 34,16 & \\
\hline
\end{tabular}

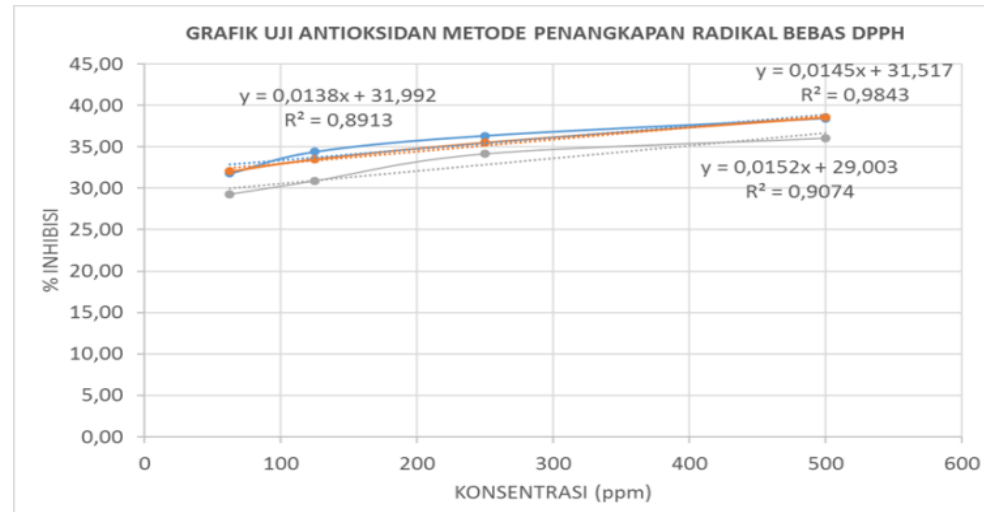

Gambar 1. Grafik Uji Antioksidan Metode Penangkapan Radikal Bebas DPPH 
Tabel 4. Nilai daya reduksi ekstrak Gracilaria verrucosa

\begin{tabular}{ccc}
\hline Ekstrak & Absorbansi 692 $\mathbf{~ m}$ & $\begin{array}{c}\text { Aktivitas Antioksidan } \\
\text { (mg AAE/gr sampel }\end{array}$ \\
\hline $\mathrm{n}$ - heksan & 0,4379 & 8,50 \\
Etil asetat & 0,7827 & 15,13 \\
Metanol & 0,3002 & 5,85
\end{tabular}

Hasil pengujian aktivitas penangkapan radikal bebas DPPH menunjukkan bahwa nilai antioksidan yang dihasilkan sangat lemah dimana untuk ketiga ekstrak memiliki nilai IC50 > 200 ppm (Mardawati et al., 2008). Aktivitas antioksidan dalam suatu sampel diduga dapat dipengaruhi oleh berbagai faktor seperti zat pengotor, parameter lingkungan pengambilan sampel dan jenis sampel itu sendiri (Leksono et al., 2018; Sedjati et al., 2018; Widowati et al., 2014). Perbedaan sampel seperti sampel kering atau basah juga ikut mempengaruhi nilai antioksidan yang terkandung didalamnya (Muzaki et al., 2017). Antioksidan ini sangat sensitive terhadap perubahan lingkungan di sekitarnya, dimana sifatnya yang mudah rusak apabila terpapar oksigen, cahaya, suhu tinggi dan pengeringan, penggunaan pelarut yang sama dapat memberikan hasil yang sangat berbeda, meskipun partikel dan stabilitas substrat sampel yang diekstraksi hampir sama (Jan et al., 2001).

\subsection{Uji Daya Reduksi}

Kekuatan daya reduksi menunjukkan bahwa senyawa antioksidan merupakan donor elektron dan dapat mengurangi terjadinya proses peroksidasi lipid dan dengan cara tersebut antioksidan dapat bertindak sebagai antioksidan primer dan sekunder (Farvin et al., 2013). Nilai pengujian daya reduksi berbanding lurus antara nilai absorbansi masing - masing pelarut sampel, dengan nilai aktivitas antioksidannya, dimana semakin besar nilai absorbansi suatu sampel, maka nilai aktivitas antioksidannya semakin naik. Hail itu disebabkan karena kandungan antioksidan yang terkandung didalamnya mampu mendonorkan elektron yang berguna untuk menutupi radikal bebas (Ganessan et al., 2007).

Hasil pengujian ini telah membuktikan penelitian yang dilakukan oleh Dutta dan Sanjib (2018), Shahwar et al., (2012) dan Faten et al., (2009) bahwa nilai total fenolat berbanding lurus dengan nilai daya reduksi, artinya semakin tinggi nilai total fenolat yang terkandung dalam suatu ekstrak, maka memiliki kemampuan daya reduksi yang tinggi.

Tingginya nilai daya reduksi dicirikan dengan absorbansi yang semakin tinggi. Kehadiran reduktan seperti antioksidan menyebabkan terjadinya reduksi Fe3+ kompleks menjadi bentuk ferrous (Chew et al., 2008; Griffin and Ranjeet, 2004), karena itu melalui pengukuran pembentukan Pearls Prussian Blue pada $700 \mathrm{~nm}$ jumlah $\mathrm{Fe} 2+$ dapat diketahui (Shahwar et al., 2012; Chew et al., 2008). Kemampuan mereduksi ekstrak kimia atau senyawa umumnya tergantung pada peran reduktan tersebut sebagai antioksidan, proses tersebut melalui pemecahan rantai radikal bebas dengan adanya donasi atom hidrogen (Akoh and Min, 2008).

Standar yang digunakan adalah asam askorbat, dalam hal ini asam askorbat berperan sebagai pembanding yang berfungsi sebagai antioksidan sekunder dengan cara menangkap radikal bebas dan mencegah terjadinya reaksi berantai. Asam askorbat termasuk kedalam golongan antioksidan sekunder yang mampu menangkal berbagai macam radikal eksogen, hal tersebut disebabkan karena asam askorbat memiliki gugus hidroksi bebas yang bertindak sebagai penangkap radikal bebas, akan meningkatkan aktivitas antioksidan jika memiliki gugus polihidroksi (Kim, 2005).

Penambahan asam trikloroasetat pada pengujian daya reduksi ini bertujuan agar kompleks kalium ferrosianida dapat mengendap dan penambahan kalium ferrisianida bertujuan untuk membentuk kompleks berwarna hijau hingga biru (Pratama et al., 2016). Pengujian antioksidan dengan metode penangkapan radikal bebas DPPH dan daya reduksi ini membuktikan penelitian yang telah dilakukan oleh Dutta et al., (2018) dan Bajpai et al., (2017) dimana nilai penangkapan radikal bebas DPPH dan daya reduksi memiliki nilai yang berbanding lurus. 


\section{KESIMPULAN}

Aktivitas penangkapan radikal bebas DPPH ekstrak Gracilaria verrucosa memiliki nilai antioksidan yang sangat lemah dengan IC50 > 1.000 ppm. Daya reduksi ekstrak Gracilaria verrucosa tertinggi ada pada ekstrak etil asetat dengan nilai 15,13 mgAAE/gr sampel, kemudian $\mathrm{n}$ - heksan 8,50 mgAAE/gr sampel dan metanol $5,85 \mathrm{mgAAE} / \mathrm{gr}$ sampel

\section{DAFTAR PUSTAKA}

Adawiyah, D.R. 1998. Kajian Pengembangan Metode Ekstraksi Komponen Antimikroba Biji Buah Atung (Parinarium glaberrimum Hassk.). Tesis Program Studi Ilmu Pangan. Program Pascasarjana IPB: Bogor.

Agregan, R., P.E. Munekata, R. Dominguez, J. Carballo, D. Franco, and J.M. Lorenzo. 2017. Proximate composition, phenolic content and in vitro antioxidant activity of aqueous extracts of the seaweeds Ascophyllum nodosum, Bifurcaria bifurcate and Fucus vesiculosus. Effect of addition of the extracts on the oxidative stability of canola oil under accelerated storage conditions. J. Food Research International., 99 : 986 994.

Akoh, C.C. and D.B. Min. 2002. Food Lipids Chemistry, Nutrition and Biotechnology 2nd Edition. Marcel Dekker Inc, New York, $1.014 \mathrm{p}$.

Almeida, C.L., H. de-S. Falcao, G.R.de-M. Lima, C. de-A. Montenegro, N.S. Lira, P.F.AthaydeFilho, L.C. Rodrigues, M.F.V de Souza, J.M. Barbosa-Filho and L.M. Batista. Bioactivities from Marine Algae of the Genus Gracilaria. International Journal of Molecular Sciences., 12; 4550 - 4573.

Amri, F.S.A. and M.A. Hossain. 2018. Comparison of Total Phenols, Flavonoids and Antioxidant Potential of Local and Imported Ripe Bananas. Egyptian Journal of Basic and Applied Sciences., 2314 - 808X

Bajpai, V.K., K.H. Baek, and S.C. Kang. 2017. Antioxidant and Free Radical Scavenging of Taxoquinone a Diterpenoid Isolated From Metasequoia glyptostroboides. South African Journal of Botany., 111: 93 - 98 pp.
Chew, Y.L., Y.Y. Lim, M. Omar, and K.S. Khoo. 2008. Antioxidant activity of Three Edible Seaweeds From Two Areas in South East Asia. J. Food Science and Technology., 41 (6): 1067 - $1072 \mathrm{pp}$.

Dutta, S. and S. Ray. 2018. Comparative Asessment of Totanl Phenolic Content and In Vitro Antioxidant Activities of Bark and Leaf Methanolic Extracts of Manilkara hexandra (Roxb.) Dubard. Journal of King Saud University - Science.

Farvin. K.H.S. and C. Jacobsen. 2013. Phenolic Compounds and Antioxidant Activities of Selected Species of Seaweeds From Danish Coast. Journal of Food Chemistry., 138: $1670-1681 \mathrm{pp}$.

Faten, M., A. Elalla, and E.A. Shalaby. 2009. Antioxidant Activity of Extracts and Semi Purified Fractions of Marine Red Macroalga, Gracilaria verrucosa. Australian Journal of Basic and Applied Sciences., 3 (4): 3179 - 3185.

Fleurence, J, and I. Levine. 2016. Seaweed in Health and Disease Prevention. British Library Catalog, London, $480 \mathrm{p}$.

Ganesan, P., C.S. Kumar, and N. Bhaskar. 2007. Antioxidant Properties of Methanol Extract and its Solvent Fractions Obtained From Selected Indian Red Seaweeds. J. Bioresource Technology., 99: 2717 - 2723.

Gordon, M., J. Pokorny, N. Yanishlieva. 2001. Antioxidant in Food: Practical Applications. British Journal of Nutrition., 87: 391.

Griffin, S.P. and R. Bhagooli. 2004. Measuring Antioxidant Potential in Corals Using the FRAP Assay. Journal of Experimental Marine Biology and Ecology., 302: 201 211.

Gritter, R.J., J.M. Bobbit, and A.E. Scwarting. 1991. Introduction to Chromatography in Practical Thin Layer Chromatography: a Multidiciplinary Approach 2nd Editio. Reinhold Books, New York, 97 - 104 pp. 
Harborne, J.B. 1987. Phytochemical Method A Guide to the Modern Techniques of Plant Analysis. Chapman and Hall Ltd, London, $286 \mathrm{p}$.

Heo, S-J., S-H. Cha, K-W. Lee and Y-J. Jeon. 2006. Antioxidant Activities of Red Algae From Jeju Island. J. Algae 21 (1): 149 - 156 pp.

Indrawati, L., A. Werdhasari, A. Yudi. 2009. Hubungan Pola Kebiasaan Konsumsi Makanan Masyarakat Miskin dengan Kejadian Hipertensi di Indonesia. MPKK., 19: $174-184 \mathrm{pp}$.

Jan, P., Yanishlieve, and Gordu. 2001. Antioxidant in Food: Practical Application. CRC Press, Boston New York USA.

Kim. S.W. 2012. Handbook of Marine Macroalgae. Biotechnology and Applied Phycology. John Wiley \& Sons Ltd, UK, 531 p.

Leksono, W.B., R. Pramesti, G.W. Santoso, dan W.A. Setyati. 2017. Jenis Pelarut Metanol dan N - Heksana Terhadap Aktivitas Antioksidan Ekstrak Rumput Laut Gelidium sp. dari Pantai Drini Gunungkidul - Yogyakarta. Jurnal Kelautan Tropis., 21 (1): $9-16$.

Leong, L.P, and G. Shui. 2002. An Investigation of Antioxidant Capacity of Fruits in Singapore Market. J. Food., 69 - 76 pp.

Lichtenthaler, H.K. and C. Buschmann. 1987. Chlorophylls and Carotenoids: Pigments of Photosynthetic Biomembranes Methods in Enzimology. Weinheim: Verlag Chemie

Maryam, St., M. Baits, dan A. Nadia. 2016. Pengukuran Aktivitas Antioksidan Ekstrak Etanol Daun Kelor (Moringa oleifera Lam.) Menggunakan Metode FRAP (Ferric Reducing Antioxidant Power). Jurnal Fitofarmaka Indonesia., 2 (2).

McCord, J.M, and Fridovitch. 1967. Superoxide Dismutase an Enzimic Function For Erythrocuprein (Hemocuprein). Journal of Biologycal Chemistry., 244 (22): 6049 $6055 \mathrm{pp}$.
Meydani, M. 2000. Effect of Functional Food Ingredients: Vitamin $\mathrm{E}$ Modulation of Cardiovascular Disease and Immune Status in the Elderly. J. Clinic Nutritions., 71.

Miliauskas, G., P.R. Venskutonis, and T.A. VanBeek. 2004. Screening of Radical Scavenging Activity of Some Medical and Aromatic Plant Extracts. Food Chemistry Journal., 85: 231 - $237 \mathrm{pp}$.

Mlodzinska, E. 2009. Survey of Plant Pigments: Molecular and Environmental Determination of Plant Colors. Acta Biologyca Cracoviensia Series Botanica. 51 (1): 7 - 16 pp.

Mulangsri, D.A.K., A. Budiarti, dan E.N. Saputri. 2017. Aktivitas Antioksidan Fraksi Dietileter Buah Mangga Arumanis (Mangifera indica L.) dengan Metode DPPH. Jurnal Pharma Science., 04 (01): 85 $-93$.

Muzaki, A.F., W.A.Setyati, dan Subagiyo. 2017.Aktivitas Antioksidan Ekstrak Rumput Laut Halimdea macroloba dari Pantai Teluk Awur, Jepara, Jawa Tengah. Journal of Marine Research.

Oyaizu, M. 1986. Studies of Product of Browning Reactions: Antioxidative Activities of Product Browning Reaction Prepared From Glucosamine. Japan Journal Nutrition., 44: 307 - 315 pp.

Picolella, S., A. Fiorentino, S. Pacifico, B. D'Abrosca, P. Uzzo, and P. Monaco. 2008. Antioxidant Properties of Sour Cherries (Prunus cerasus L.): Role of Colorless Phytochemicals from the Methanolic Extract of Ripe Fruits. Journal of Agriculture and Food Chemistry., 56 (6): $198-1935$ pp.

Pise, N.M., D. Maharana, K. Jena, and T. Jagtap. 2010. Free Radical Scavenging, Reducing Power, Phenolic and Biochemical Composition of Porphyra species. Journal of Algal Biomass., 1 (2): 60 - 73 pp.

Pramesti, R., A. Ridlo, W.A. Setyati, M. Zainuddin, dan M.R. Akbar. 2017. Aktivitas 
Antioksidan dan Rumput Laut Acanthophora muscoides (Linnaeus) Bory dari Pantai Krakal Gunungkidul Yogyakarta. Jurnal DISPROTEK., 8 (1).

Pratama, M., A. Muflihunna dan N. Octaviani. 2018. Analisis Aktivitas Antioksidan Sediaan Propolis yang Beredar di Kota Makassar dengan Metode FRAP (Ferric Reducing Antioxidant Power). Jurnal As Syifaa., 10 (01): 11 - 18 pp.

Raudonis, R., L. Raudone, V. Jakstas, and V. Janulis. 2012. Comparative Evaluation of Post Column Free Radical Scavenging and Ferric Reducing Antioxidant Power Assays For Screening of Antioxidants in Strawberries. J. Chromatography A., 1233: $8-15 \mathrm{pp}$.

Sedjati, Sri., E. Supriyantini, A. Ridlo, N. Soenardjo. dan V.Y. Santi. 2018. Kandungan Pigmen, Total Fenolik, dan Aktivitas Antioksidan Sargassum sp. Jurnal Kelautan Tropis., Vol 21 (2): 137 - 144 pp.
Shahwar, D., M.A. Raza, S. Bukhari, and G. Bukhari. 2012. Ferric Reducing Antioxidant Power of Essential Oils Extracted From Eucalyptus and Curcuma species. Asian Pasific Journal of Tropical Biomedicine., S1633 - S1636.

Sheikh, T.Z.B., C.L. Yong, and M.S. Lian. 2009. In Vitro Antioxidant Activity of the Hexane and Methanolic Extract of Sargassum baccularia and Cladophora patentiramea. Journal of Applied Science., 13 (9): 2490 $2493 \mathrm{pp}$.

Tahir, M., A. Cahya. H, dan H. Widiastuti. 2016. Uji Aktivitas Antioksidan Buah Semangka (Citrullus lanatus) dengan Metode FRAP. Jurnal As - Syifaa., 8 (01): 31 - 38 pp.

Wijaya, A. 1996. Radikal Bebas dan Parameter Status Antioksidan. Forum Diagnostikum Prodia. Diagnostics Educational Center, 1 12. 